\title{
Research on Comprehensive Evaluation System of Training Base in Higher Vocational Colleges under the Mode of School Enterprise Cooperation
}

\author{
Qingyun Meng \\ Department of Mechanical Engineering, Dalian Vocational \& Technical College, Dalian, Liaoning, China \\ 874702490@qq.com
}

Keywords: Higher vocational colleges, school enterprise cooperation, training base and evaluation system

\begin{abstract}
Building the training base for school and enterprise is the only way for the development of practical training teaching in higher vocational colleges. The key point is to define the stakeholders of the school enterprise cooperation and build the training base as the evaluation subject, and to determine the evaluation principles, methods and indexes, so as to achieve the University. The purpose of enterprise cooperation is initiative and enthusiasm. So as to achieve the goal of improving the quality of personnel training in higher vocational colleges, promoting enterprise progress and improving the quality of school enterprise cooperation.
\end{abstract}

\section{Introduction}

According to the requirements of the national medium and long term education reform and development plan (2010 - 2020), higher vocational colleges must carry out the training mode of the cooperation between school and enterprise, and gradually establish the mechanism of running a school with the joint participation of the government, the bank, the enterprise and the school. Under the guidance of the government and the industry association, it will make the school enterprise cooperation. To promote the institutionalization of school enterprise cooperation. The cooperation of school and enterprise to build training base is a deep water area for the reform of higher vocational education. It is also an effective way to improve the ability of running a school and practice the ability of students. It needs to be continuously explored. Improving the connotation construction of higher vocational education and implementing school enterprise cooperation are the key.

\section{The Main Problems of Training Base in Higher Vocational Colleges Under the Mode of School Enterprise Cooperation.}

At present, many higher vocational colleges are committed to exploring the ways and methods of school enterprise cooperation, and the research work on school enterprise cooperation is mainly focused on the way of realizing the cooperation between school and enterprise. How to evaluate the performance of school enterprise cooperation is still relatively blank.

At present, the general situation of school enterprise cooperation training base is heavy investment and construction, less evaluation and evaluation. Such training bases are generally invested heavily, but there is no sound evaluation system for the promotion of education and teaching and the effect of serving the society after completion. Without evaluation system, it is impossible to assess the economic and social benefits of the training base. When carrying out follow-up projects, there is no evaluation system that can be used for reference.

From the current research situation, the evaluation of the school enterprise cooperative training base is mainly from two aspects of the school enterprise cooperation and the service of scientific and technological research and development. In the analysis of the above research work, it is found that in the evaluation index of the existing school enterprise cooperative training base, the training function of the school enterprise cooperation and the research and development function of science 
and technology are usually separated. In view of the method, there is still a lack of solid theoretical basis; in addition, from the number and source journal of the publication of the paper, the evaluation of the school enterprise cooperation and co construction of practical training base has not yet aroused the attention of the academic circle.

\section{The Significance of the Comprehensive Evaluation System of Training Bases In Higher Vocational Colleges Under the Mode Of School Enterprise Cooperation.}

School enterprise cooperation is the basic way to realize the training target of higher vocational colleges. The evaluation of the effectiveness of school enterprise co construction training base can help schools and enterprises find the weak points of school enterprise cooperation, clear the direction of the work of school enterprise cooperation and promote the development of school enterprise cooperation. On the other hand, in the work of school enterprise cooperation, we should give full consideration to the interests of enterprises and explore ways of cooperation between schools and enterprises based on interests. Therefore, exploring the comprehensive evaluation system of the effectiveness of training bases under the mode of school enterprise cooperation plays a significant and positive role in the improvement and sustainable development of school enterprise cooperation.

(1) The evaluation plan and evaluation system are programmatic documents. The evaluation system should play a reasonable role in evaluating the investment, construction, implementation, management and use of training bases. Therefore, a scientific and reasonable evaluation system for training bases is a yardstick for guiding the construction, management and use of training bases.

(2) When evaluating according to the evaluation system, data need to be collected, sorted and analyzed to form quantitative data. In this process, we can identify the advantages and disadvantages of training base construction, management and utilization. And then carry forward the advantages and improve the shortage. The training base is optimized continuously.

(3) The results of the training base evaluation system include two aspects: 1) providing evaluation information for leaders. It is used to improve management and policy level decision-making and guidance; 2) to provide feedback for the evaluators. The role of evaluation and feedback is no more than to develop and avoid weaknesses. Through the evaluation results, we should carry forward the advantages and improve the deficiencies. Thus, it can stimulate the construction, management and use of training bases.

\section{Method.}

\subsection{A Comprehensive Evaluation System for Training Bases in Higher Vocational Colleges Under the Mode of School Enterprise Cooperation.}

The training base is special in its use and the subject of all people. It takes into account the specialized factors of the training base, the location of the training base (the campus or the outside school), whether it is shared, whether it is common management, and whether it is convenient for management, with the principles of guiding, comprehensiveness and maneuverability, and adopting the analytic hierarchy process (AHP), Case analysis, literature collection and logical analysis are used to design the evaluation index of the school enterprise cooperative training base in accordance with the following principles, and to build a comprehensive evaluation system for the effectiveness of the training base under the model of school enterprise cooperation.

\subsubsection{Systematic Principle.}

Because the various evaluation subjects (schools and enterprises) have differences in interest demand, value orientation, evaluation vision, evaluation error, evaluation limitation and the quantity and accuracy of information mastery, the composition and weight distribution of the evaluation subject have an important influence on the results of the actual effectiveness evaluation of higher vocational school enterprise cooperation. . Therefore, we must systematically build a main body system of the effectiveness evaluation of school enterprise cooperation in Higher Vocational 
Colleges and achieve all-round and multi angle evaluation.

\subsubsection{Balance.}

The principle of balance of interests in the evaluation of school enterprise cooperation in higher vocational colleges is concerned with the balance of interests among key stakeholders involved in each goal level. (1) combining the interests balance of stakeholders with the goal decomposition of school enterprise cooperation, the overall goal of school enterprise cooperation is decomposed to all levels of stakeholders, and the interests of the stakeholders are consistent with the overall interests of the school enterprise cooperation. (2) to determine the key stakeholders of the school enterprise cooperation at each target level. To design the key indicators of effectiveness evaluation of this goal level.

\subsubsection{The principle of Sustainability.}

The principle of sustainability requires that the school enterprise cooperation in higher vocational colleges should have a series of dynamic development goals to closely adapt to the changes in the conditions of cooperation or cooperation, and the results of the effectiveness evaluation should be the organic combination of the short-term goals and the long-term goals. The principle of sustainability emphasizes the role of the stakeholders in school enterprise cooperation, stimulates the participation of the weak stakeholders, takes full consideration of the positive and negative effects and negative effects of the school enterprise cooperation, and attaches great importance to the establishment and maintenance of the environmental basis for sustainable utilization, and continues to integrate all kinds of resources into the school enterprise cooperation.

\subsection{To Form Feedback on the Comprehensive Evaluation System of the Effectiveness of Training Bases under the Mode of School Enterprise Cooperation.}

After the completion of the compilation, the more important thing is how to implement it. In order to make the evaluation system play a role, other supporting measures are needed. Priority should be given to selecting a good training base for school enterprise cooperation as the primary object of evaluation. After successful application, it will gradually expand to other training bases. At the same time, through interviews, data access and network data search methods, the implementation of the comprehensive evaluation system of training base effectiveness under the mode of school enterprise cooperation is put forward. The problems existing in the implementation of the evaluation system are also analyzed. According to the results of the evaluation

Perfect the comprehensive evaluation system of training base effectiveness under the mode of school enterprise cooperation.

\section{Conclusion}

In order to effectively evaluate the quality of the school enterprise cooperation and build the quality of the training base, it is an urgent need to improve the cooperation level of the school and enterprise. The key point is to define the stakeholders of the co construction training base as the evaluation subject, and to determine the evaluation principles, methods and indicators, so as to fully mobilize the initiative of the stakeholders to improve the effectiveness of the school enterprise cooperation. And the purpose of the initiative. So as to achieve the goal of improving the quality of personnel training in higher vocational colleges, promoting enterprise progress and improving the quality of school enterprise cooperation.

\section{References}

[1] Dai Jianhua. Practice and Research on the construction of "teaching factory" training base, taking the project of engineering training center of Wuxi Institute of Commerce as an example [J], Wuxi Institute of Commerce, 2011 (6).

[2] Jin Furong, Luo Sai Qi. Research on performance evaluation index system of industry university 
research cooperation [J]. Scientific Management Research, 2009 (3): 45.

[3] Wang Deng Zhou. Based on the evaluation of "high interest" to promote the all-round development of students [J] Journal of Liaoning Institute of Education Administration, 2014 (1): 45-49.

[4] Liu Jianqi, Zhang Yan Lin. On the development of the school enterprise cooperation mechanism in foreign countries [J]. University Education, 2014 (1)

[5] Yi New River, Wen Yimin, Chen Zhiyong. A summary of twenty years' research on school enterprise cooperation in China [J]. Higher Education Forum, 2014 (02).

[6] Hongmei Yan. The present situation and countermeasure analysis about the coordinated development under the perspective of higher vocational education development [J]. Education and Vocation, 2012(27):16-18. 